\title{
Extraction of Proteins and Pasting and Antioxidant Properties of Soybean Hulls
}

\author{
Sean X. Liu ${ }^{1}$, Diejun Chen ${ }^{1}$, Mukti $\operatorname{Singh}^{1} \&$ Jingyuan $\mathrm{Xu}^{2}$ \\ ${ }^{1}$ Functional Food Research Unit, National Center for Agricultural Utilization Research, USDA-ARS. 1815 N \\ University Street, Peoria, IL 61604, USA \\ ${ }^{2}$ Plant Polymer Research Unit, National Center for Agricultural Utilization Research, USDA-ARS. 1815 N \\ University Street, Peoria, IL 61604, USA \\ Correspondence: Sean X. Liu, Functional Food Research Unit, National Center for Agricultural Utilization \\ Research, USDA-ARS. 1815 N University Street, Peoria, IL 61604, USA. Tel: 1-309-681-6551. E-mail: \\ Sean.liu@ars.usda.gov
}

Received: August 30, 2019

Accepted: October 5, 2019 Online Published: October 17, 2019

doi:10.5539/jfr.v8n6p66

URL: https://doi.org/10.5539/jfr.v8n6p66

\begin{abstract}
Soybean hulls are a by-product from soybean processing for oil and meal production which comprise approximately $8 \%$ of the whole seed. This study investigated water holding capacities and pasting properties, and first reported the phenolic contents and antioxidant activities from soybean hulls which are important to our long-term health. In addition, the conditions for extracting proteins from soybean hulls including optimum $\mathrm{pH}$, as well as homogenizing and separation methods for extraction, were also studied. Higher protein content in extracts and recoveries was obtained with extraction at $\mathrm{pH}$ 9. Using sieve separation may be an effective way to extract proteins from hulls for industrial applications. The precipitated protein content increased from $51.52 \%$ to $59.29 \%$ after purification by washing with water once; however, after two washes, no further improvement was shown. The extracted proteins can be used for food applications. The ground hull powders (10\% protein), dried supernatant (14\% protein) and sediments (7-8\% proteins) along with valuable fibers should be good food ingredients for several food categories. This research explored the great potential of converting the low value by-products into value-added functional food uses along with the benefit of reducing food and agricultural wastes.
\end{abstract}

Keywords: antioxidation, extracting, pasting, $\mathrm{pH}$, proteins, soybean hull, water holding capacity, food product

\section{Introduction}

Soybean hull, a by-product of soybean processing for oil and meal production, comprises approximately $8 \%$ of the whole seed (Gnanasambandam \& Proctor, 1999). It contains $12 \%$ crude protein, $2 \%$ fat, and $61 \%$ of neutral detergent fiber (Extension, 2019), and is currently used as supplemental feed for dairy cattle since they are low in lignin, their cellulose is highly digestible (85\%) in the rumen, and fermentation rates are rapid (Stein et al., 2008). Soy hulls may also be used as energy supplements to high forage diets of lambs and steers (Anderson, et al., 1988).

The estimated yield of soybean hulls from a 60-pound bushel of soybeans is about three pounds, or approximately $5 \%$ of the original raw soybean weight. Based on this yield, the harvest projections for a one-year soybean crop in the state of Kansas could result in the production of almost 115,000 tons of soybean hulls (Kansas State University Agricultural Experiment Station and Cooperative Extension Service, 2019), indicating the great potential for this research. There is a great amount of information on separating protein from soybean seeds. Soy protein isolate is traditionally prepared from defatted soy meal using aqueous or mild alkali extraction (pH7-10) of proteins and soluble carbohydrates (Liu K., 1999). There is research on extracting protein using soybean hulls, such as a previous study in which the air classification of milled hulls was used to enrich these value-added proteins at various $\mathrm{pH}$ from 2.5 to 6.4 (Sessa, 2004). However, there was inadequate information on extracting protein from soybean hull. Furthermore, little was known on the commercial usage of soybean hulls for food beyond the use in animal feed.

As a low-value processing by-product containing valuable components, soybean hulls have the potential to be 
turned into high value food and consumer products through innovative technologies. However, information on utilization of soybean hulls for food and non-food products is limited. This study investigated physicochemical properties of finely-milled soybean hulls that are important for developing food products and explored extraction methods for producing protein rich fractions for functional food ingredients based on particle size, $\mathrm{pH}$ value, and extraction solvent. Oxidative stress has been identified as the root cause for the development and progression of several diseases (Kasote et al., 2015). There is study reported on antioxidant activity of soybean but not on soybean hulls. Therefore, the phenolic contents and antioxidant activity in soybean hulls were examined in this study. The goal of this study is to reduce food and agricultural waste in soybean processing and enhance overall value of soybean crop by generating value-added products from the low value feedstock.

\section{Materials and Methods}

\subsection{Materials}

Organic soybean hulls (OSH) were obtained from Keystone Mills (Ephrata, PA, USA). Inorganic pelletized soybean hulls (ISH) (GMO) were obtained from Archer-Daniels-Midland (Quincy, IL, USA). Soybean flour was bought from Bob's Red Mill (Natural Foods, Inc., Milwaukie, OR, USA), and oat bran powder was purchased from Grain Millers (Eden Prairie, MN, USA). Sodium hydroxide was obtained from A division of EM industries, Inc., NJ, USA. Sodium hydroxide was purchased from Fisher Chemicals (Fair Lawn, NJ, USA).

\subsection{Protein Extraction Procedures}

Processing procedures were adopted from a previous method with modifications (Liu, 1999). The procedure is shown in Figure 1. We examined the effects of particle size of ground hulls, defatting, pH, type of alkali, and homogenization/separation methods on protein extraction.

\subsubsection{Grinding Soy Hull}

Soy hull were ground IKA mill (M20, IKA ${ }^{\circledR}$ Works, Inc., NC, USA), and passed through a sifter with a 50-mesh screen.

\subsubsection{Defatting}

The defatted soyhulls were accomplished using a Soxhlet extractor with hexane for $12 \mathrm{~h}$.

\subsubsection{Homogenization Methods}

Ground soybean hull powder was mixed with water, or soybean hulls were homogenized using a commercial heavy-duty Waring blender (Model 37BL84, Dynamics Corporation of America, New Hartford, CT, USA) for 3 min, or a Polytron (PT6000, Kinematica AG, Littau, Switzerland) at about 3,000 rpm before increasing the rpm to about 5000 with water for $3 \mathrm{~min}$.

\subsection{4 pH Adjustment}

Processing procedures were adopted from a previous method with modifications (Liu, 1999). The pH of the mixture was adjusted to $\mathrm{pH} 7.5,9,10$, or 11 using $\mathrm{Na}(\mathrm{OH})$ solution, respectively, and stirred by a magnetic bar for $1 \mathrm{~h}$.

\subsubsection{Separation Methods}

The extract was centrifuged for 10 minutes at $3000 \mathrm{rpm}$ or separated by a sieve with 100 mesh screens. The sediments from centrifugation or sieve top were dried at $60{ }^{\circ} \mathrm{C}$ in an oven for further testing.

\subsubsection{Protein Precipitation}

The $\mathrm{pH}$ of the suspension was adjusted to $4.5 \mathrm{using} \mathrm{HCl}$ solution and centrifuged for $10 \mathrm{~min}$ at $3000 \mathrm{rpm}$. The precipitates and sediments were dried directly or washed $1-2$ times at $40{ }^{\circ} \mathrm{C}$ in an oven. 


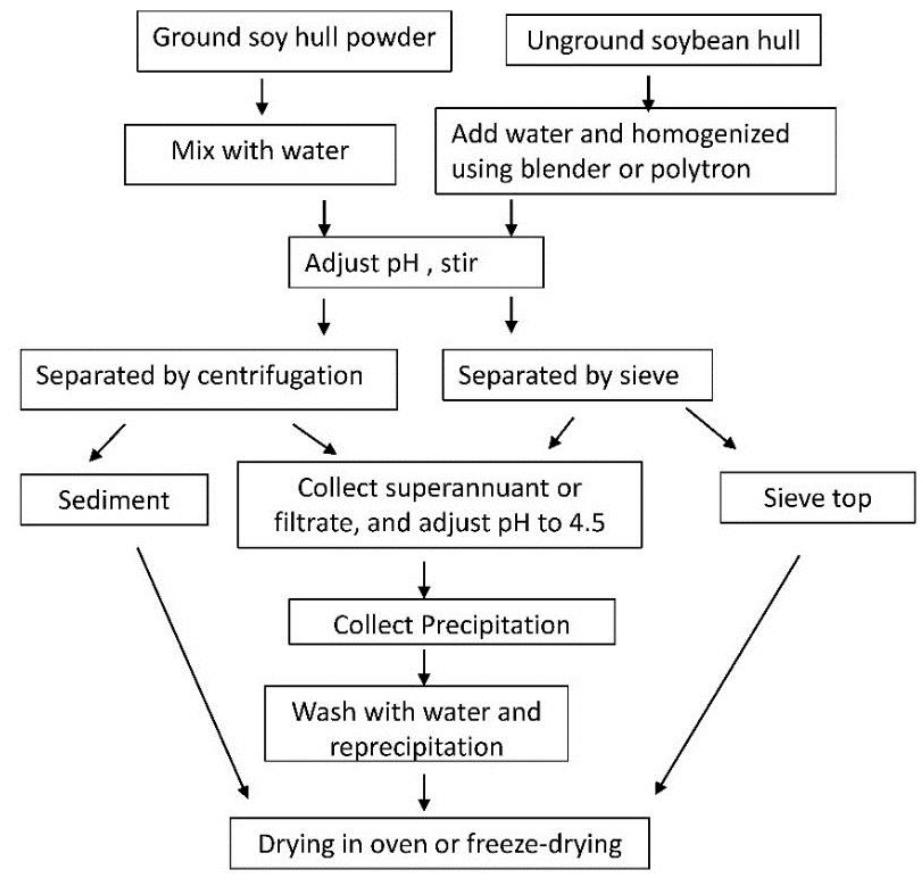

Figure 1. Flow chart of procedures for extracting protein from soybean hulls

\subsection{Composition Determination}

Total solid and moisture contents were determined by drying $5 \mathrm{~g}$ of sample at $105^{\circ} \mathrm{C}$ to a constant weight. Protein was determined by the combustion method using Leco CHN (St. Joseph, MI, USA) with a protein correction factor of $\% \mathrm{~N} \times 6.25$ (American Association of Cereal Chemists, 1995). Ash content was determined gravimetrically after combustion at $525^{\circ} \mathrm{C}$ for $12 \mathrm{~h}$.

\subsection{Total Phenolic Content}

Phenolic content was determined by the Folin-Ciocalteau colourimetric method with minor modifications (Waterhouse, 2001; Yu and Zhou, 2004). To $100 \mu \mathrm{L}$ of extract, $7.9 \mathrm{~mL}$ of deionized water and $0.5 \mathrm{~mL}$ of Folin-Ciocalteau reagent (F9252, Sigma Aldrich, St Louis, MO, USA) were added, mixed using a vortex mixer, and $1.5 \mathrm{~mL}$ of $1.85 \mathrm{M} \mathrm{Na}_{2} \mathrm{CO}_{3}$ was added after $15 \mathrm{~min}$. Absorbance of samples was measured at $765 \mathrm{~nm}$ after $2 \mathrm{~h}$. Gallic acid was used as a standard and results were expressed as $\mathrm{mg}$ of gallic acid equivalents per $\mathrm{g}$ (d.m.).

\subsection{Antioxidant Activity}

Antioxidant activity determination was conducted using a method reported by Yu et al. (2004) and Şensoy et al. (2006), which entailed reacting $0.5 \mathrm{~mL}$ of extract with $0.5 \mathrm{~mL}$ of $200 \mu \mathrm{M}$ 2, 2-diphenyl-1-picryl-hydrazyl (DPPH) in a cuvette for $40 \mathrm{~min}$ in the dark. The cuvettes were converted after adding reagent and prior to reading the absorbance at $515 \mathrm{~nm}$. Results were expressed as 6-hydroxy-2, 5, 7, 8-tetramethylchroman-2-carboxylic acid (Trolox) equivalents per g (d.m.).

\subsection{Water Holding Capacity}

Water holding capacity of flours was determined according to the procedure of Ade-Omowaye et al. (2003) with some modifications. Briefly, flour samples $(2 \mathrm{~g})$ were mixed with $25 \mathrm{~g}$ of deionized water and vigorously mixed using a vortex to make a suspension, then held for $2 \mathrm{~h}$, followed by centrifugation at $1,590 \mathrm{~g}$ for $15 \mathrm{~min}$. Water was removed by pipette and measured. Each treatment was replicated twice. Water-holding capacity was calculated by the following equation:

Water holding capacity $(\%)=[$ Water added $(\mathrm{g})$-decanted water $(\mathrm{g})] /$ dry sample weight $\mathrm{g} * 100$

\subsection{Pasting Property Measurement}

The pasting properties of samples were measured using a Rapid Visco Analyzer (RVA-4, Perten Scientific, Springfield, IL, USA) by a method described by Kaur and Singh (2006) with some modifications. Samples (2.8, $3.92,4.48 \mathrm{~g}$ d.b.) were made up to a total weight of $28 \mathrm{~g}$ with distilled water in an RVA canister $(10,14,16 \%$ 
solids, w/w). The viscosity of the samples was monitored during the heating and cooling stages. Suspensions were equilibrated at $50^{\circ} \mathrm{C}$ for $1 \mathrm{~min}$, heated to $95^{\circ} \mathrm{C}$ at a rate of $6.0^{\circ} \mathrm{C} / \mathrm{min}$, maintained at $95^{\circ} \mathrm{C}$ for $5 \mathrm{~min}$, and cooled to $50^{\circ} \mathrm{C}$ at a rate of $6.0^{\circ} \mathrm{C} / \mathrm{min}$, and held at $50^{\circ} \mathrm{C}$ for $2 \mathrm{~min}$. For all test measurements, a constant paddle rotating speed $(160 \mathrm{rpm})$ was used throughout the entire analysis except for $920 \mathrm{rpm}$ in the first $10 \mathrm{~s}$ to disperse samples. Each sample was analyzed in duplicate.

\subsection{Statistical Analysis}

All data from triplicated samples were analysed with analysis of variance using Duncan's multiple comparison to determine significant differences $(P<0.05)$ between treatments (SAS Institute, 1999).

\section{Results and Discussions}

\subsection{Compositions}

Organic soybean hulls (OSH) contain water (6.56\%), protein (9.96\%), lipids (1.54\%), and ash (4.87\%), and the remaining content is estimated to contain fiber and carbohydrates (77.07\%) (Figure 2). The protein content in OSH (9.96\%) is higher than inorganic soybean hulls (ISH) $(8.50 \%$,) in this study (Figure 3). The protein contents slightly increased after defatting (Figure 3). Research by Sessa (2004) found the finely ground fractions, with particle sizes ranging from $<15$ to $18 \mu \mathrm{m}$, were enriched with nitrogen and lipid when compared with the more coarsely ground fractions. Therefore, the compositions of soybean hulls could be affected by particle sizes.



Figure 2. Compositions of organic soybean hulls

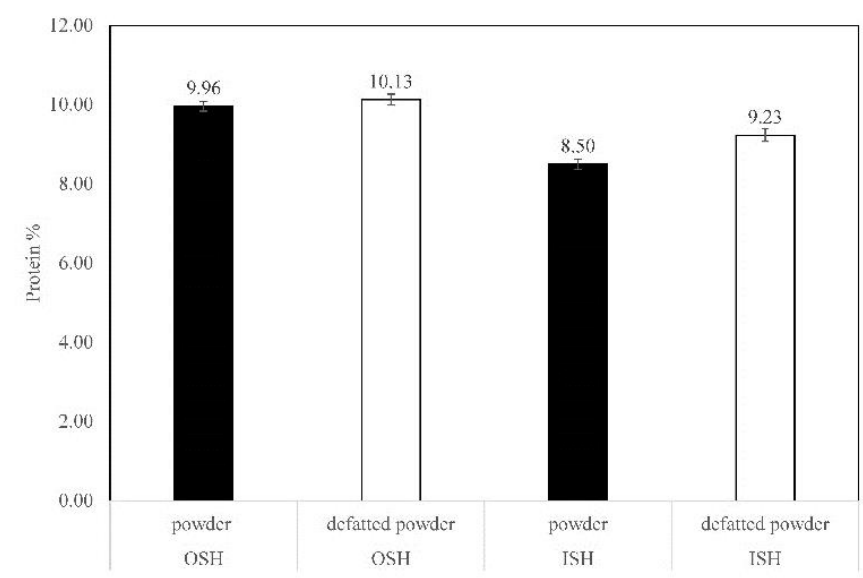

Figure 3. Protein contents of organic soybean hulls (OSH) and inorganic soybean hulls (ISH) 


\subsection{Antioxidant Activities}

Phenolic acids are readily absorbed through the walls of human intestinal tract, and they may be beneficial to health because they work as antioxidants that prevent cellular damage due to free-radical oxidation reactions (Dyke \& Rooney, 2007). They may also promote anti-inflammatory conditions in your body when people eat them regularly (Dyke \& Rooney, 2007). Therefore, phenolic compounds in and antioxidant activities of soybean hulls were investigated. Oat bran was included in the test since it is also a seed coating and a well-known for its health-promotion properties. As a reference, oat bran, which is well known as a healthy food for reducing cholesterol, contain $0.93 \mathrm{mg} / \mathrm{g}$ phenolic compounds. Although the phenolic compounds $(1.76 \mathrm{mg} / \mathrm{g})$ in soybean hulls were much lower than soybean flour $(3.65 \mathrm{mg} / \mathrm{g}$ ), phenolic compounds in soybean hulls were significantly higher $(p<0.05)$ than oat bran (Figure 4). It may be that soy hulls contain less free phenolic compounds because phenolic compounds are tightly bound in and between fibers. On the other hand, soybean hulls show substantially higher $(p<0.05)$ antioxidant activity $(3.06 \mu \mathrm{mol} / \mathrm{g})$ than soybean flour $(0.80 \mu \mathrm{mol} / \mathrm{g})$ and oat bran $(1.89 \mu \mathrm{mol} / \mathrm{g})$ (Figure 5). The defatted hulls had slightly lower antioxidant activity $(2.69 \mu \mathrm{mol} / \mathrm{g})$ than undefatted hulls, suggesting some liposoluble antioxidants were removed by the defatting procedure. Foods rich in antioxidants provide a promising way of combating the undesirable effects of reactive oxygen species induced oxidative damage in human body (Kasote et al., 2015). Thus, soybean hulls should be useful as functional food ingredients because they not only contain proteins and valuable fibers, but also exhibit good antioxidant activity.

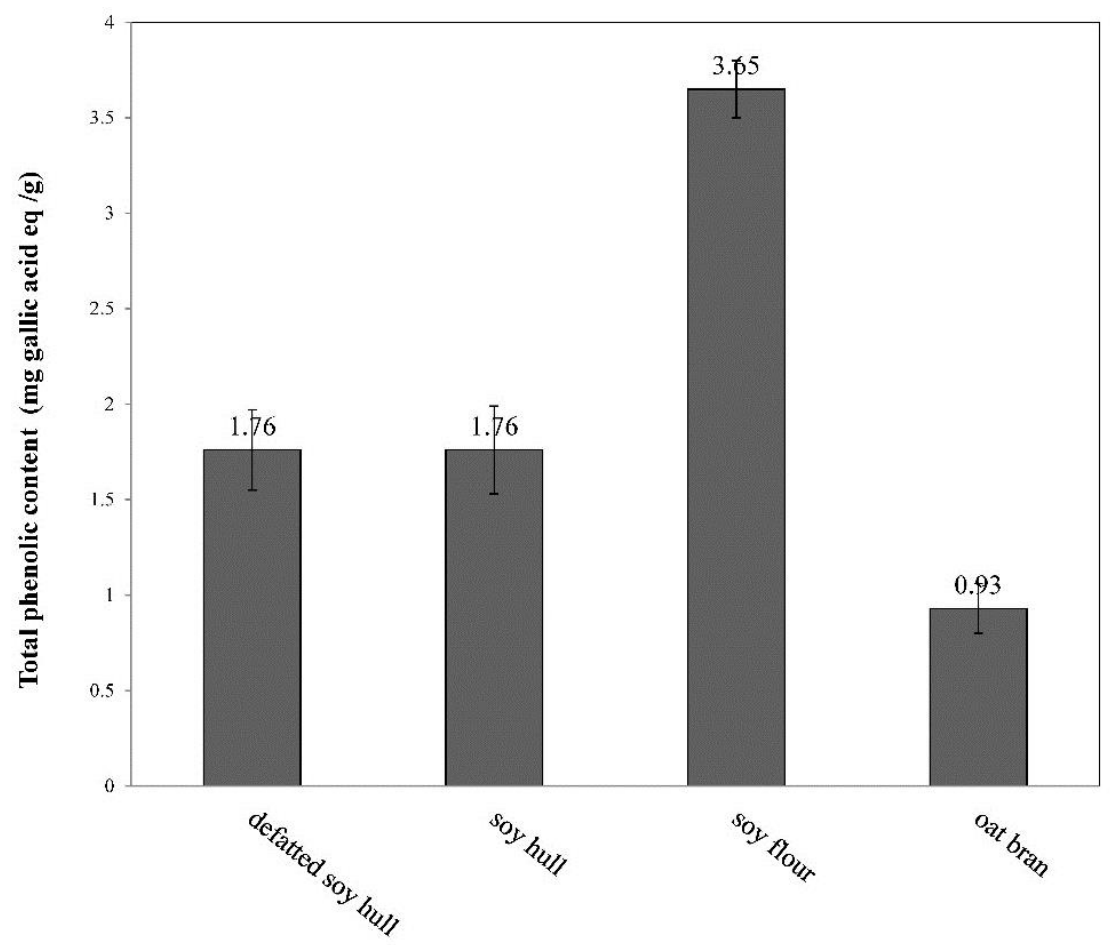

Figure 4. Phenolic contents of organic soybean hulls, soy flour and oat bran 


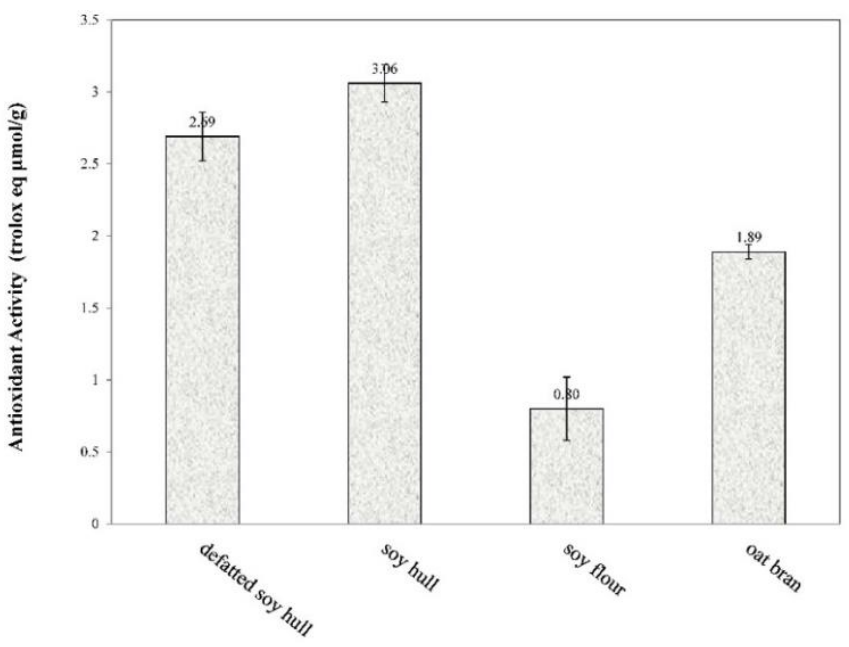

Figure 5. Antioxidant activities of organic soybean hulls, soy flour, and oat bran

\subsection{Water Holding Capacity (WHC)}

Water holding capacity (WHC) is an important property related to many quality traits of an emulsion, such as viscosity and stability. We found that WHC of soybean hulls was affected by soy hull particle size and acidic/alkali treatment of hulls $(\mathrm{pH})$. The WHC of 20 mesh soybean hulls was somewhat higher $(483.1 \mathrm{~g} / 100 \mathrm{~g})$ than that of 50 mesh soybean hulls $(405.4 \mathrm{~g} / 100 \mathrm{~g})$ (Table 1). Water holding capacities became lower when the sizes of soybean hulls were smaller. This result suggested that WHC could be influenced by fiber structures and composition of the soy hull fractions. The water may reside inside fiber pores or bound to cellulose fibrils or proteins through hydrogen bonding. The high WHC might be attributed to the loose fibril arrangement, branched structures, large pore size, high hydrophilic surface area per unit mass or high hydrophilic nature (Qui et al., 2017). The large pores formed with fibers and branched structures were damaged by grinding, resulting in low water holding capacities.

Correspondingly, considerable reductions of $48 \%$, and $39 \%$ were observed for 50, and 20 mesh hulls with acidic treatments (Table 1). This is consistent with a study reported by Marshall et al. (2000) where soy hulls were treated for absorption of metal ions. For soybean hulls, a $26 \%$ increase in adsorption capacity was detected after $\mathrm{NaOH}$ treatment compared with water washing. However, the capacity was significantly reduced (about 78\%) after washing with $\mathrm{HCl}$ (Marshall et al., 2000). Acid-washed hulls caused the adsorbent surface to be protonated (Marshall et al., 2000) reducing the likelihood of hydrogen bond-like binding between electronegative atom and $\mathrm{H}$ atoms. Hydrogen bonds are not just formed between water molecules; they can form, to varying degrees, between $\mathrm{H}$ atoms and electronegative atoms such as $\mathrm{O}, \mathrm{N}, \mathrm{F}$, and $\mathrm{Cl}$ (Israelachvili, 2011). A clear trend was observed for the water solubility. Water solubility was very low for soybean hulls. The soluble solids in 50 mesh and 20 mesh soybean hulls were unmeasurable under test conditions in this study, indicating high content of insoluble fibers and proteins in soybean hulls.

Table 1. Water holding capacities of soybean hulls with different sizes and $\mathrm{pH}$

\begin{tabular}{ll}
\hline & Water holding capacity $^{1}(\%)$ \\
\hline 20 mesh-pH7 & $483.10 \pm 3.88^{\mathrm{a}}$ \\
20 mesh-pH4.5 & $443.96 \pm 0.09^{\mathrm{b}}$ \\
50 mesh-pH7 & $405.36 \pm 0.80^{\mathrm{c}}$ \\
50 mesh-pH4.5 & $357.32 \pm 7.69^{\mathrm{d}}$ \\
\hline
\end{tabular}

${ }^{1}$ Means followed by the same letter within the same column are not significantly different $(P<0.05)$.

\subsection{Pasting Properties}

Pasting properties of soybean meal were frequently reported. However, there is no literature focused on pasting properties of soybean hulls. The rapid pasting viscosity (RVA) data were useful since it could provide information for food handling during food processing. RVA pasting data disclosed the changes of sample viscosities during heating and cooling. Pasting properties are displayed in Figure 6. In general, the viscosity of 
soybean hulls suspension increased as the amount of soybean hulls in the pasting increased. The viscosity for $10 \%$ soybean hull suspension for all sizes remained essentially unchanged during heating and shearing, exhibited a flat pasting curve, and had lower final viscosity compared to the viscosities for $14 \%$ and $16 \%$ soybean hulls. The viscosities of samples containing $14 \%$ and $16 \%$ soybean hulls increased gradually during heating and shearing and showed high final viscosity at $50^{\circ} \mathrm{C}$ after cooling. This increased viscosity could be due to interaction of swollen fibers and proteins during cooling to form a stable matrix with greater stability under heating and shearing. In general, viscosities for all pasting with 20 mesh soybean hulls were found to be much greater than that of 50 mesh soybean hulls. The fiber structures of soybean hulls likely attributed to these higher viscosities. The trend of final peaks from pasting appeared to be related to their water holding capacities. The above results suggested that processing 50 mesh soybean hulls would consume lower energy.

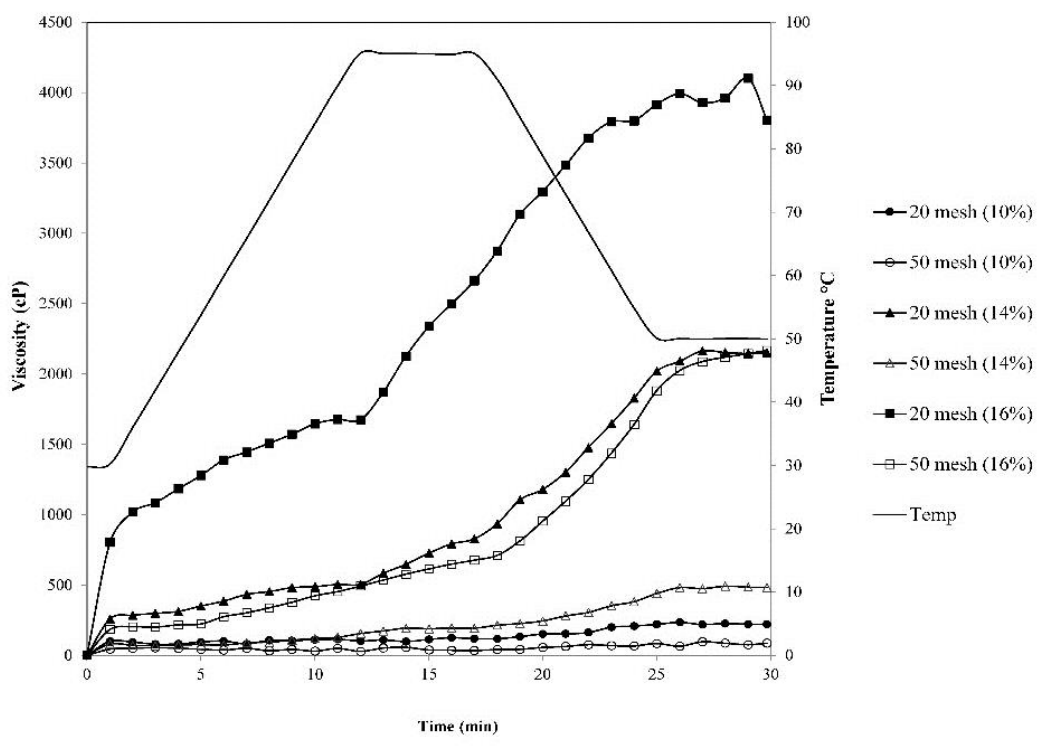

Figure 6. Pasting properties of organic soybean hulls with different sizes and solids

\subsection{Extraction of Protein-Rich Products}

\subsubsection{Effect of $\mathrm{pH}$ and Water Temperature}

It was previously found the preferred $\mathrm{pH}$ for protein extraction from soybean flour was between $\mathrm{pH} 7.5$ and 9.0 (Berk, 1992). Proteins retained their native conformation in films at $\mathrm{pH} 8$ but were partially or extensively denatured at pH 11 and 2 (Mauri \& Añón, 2006). Thus, soybean hulls were extracted using water at pH 7.5, 9, 10, and 11 (Table 2). The soybean hulls extracted at pH 9 had the highest protein content (T3: 52.58\%) and the hulls at $\mathrm{pH} 10$ was the second highest protein content (T4: 51.52\%), while the hulls extracted at $\mathrm{pH} 7.5$ was the lowest (T1: $38.54 \%$ ). Overall, $\mathrm{pH} \mathrm{9-10} \mathrm{is} \mathrm{the} \mathrm{ideal} \mathrm{pH}$ condition, resulting in higher protein contents (about 52\%) in the extracted solids from the starting soybean hulls containing $10 \%$ protein (Table 2). Although the soybean hull powders extracted at $9 \mathrm{pH}$ had the lowest protein content (T2: $30.35 \%$ ), they had the highest protein recovery (24.64\%) among all extractions using soybean hull powder due to the highest solids obtained from hot extraction. This implies that hot water probably increased the solubility, and the protein recoveries were the functions of both extracted solids and protein content. The suspension of defatted soybean hulls with double hot water extractions could not be separated after $\mathrm{pH}$ was adjusted to 4.5. The reasons are probably due to the hull suspension that was emulsified by double hot extractions, and particles with proteins could not precipitate during centrifugation (Table 2, T7).

\subsubsection{Effect of Defatting}

The extracted protein content (Table 2, T6: 52.75\%) with recovery $(26.38 \%)$ from defatted hull powders was the highest protein content among the extractions, which may be contributed to easy separation without interference of emulsification by lipids. However, defatting incurs additional energy and costs. Also, residual solvent from defatting could be a problem if soybean hulls are used as food ingredients. Overall, for protein extraction from soybean hulls, defatting is a costly unnecessary step. 


\subsubsection{Hulls versus Powders}

When extracting protein from hulls, soybean hulls were soaked for $1 \mathrm{~h}$ and blended for 3 min before stirring and $\mathrm{pH}$ adjusted to the desired value. In Table 2, the protein content (T8: 45.85\%) from soybean hulls was lower than soybean powder at the same $\mathrm{pH}(\mathrm{pH}=9)($ Table 2, T3: 52.58\%). However, extracted soybean hulls at $\mathrm{pH} 9$ accomplished the highest protein recovery (T8: $28.59 \%)$ due to the high solids collected ( $0.53 \mathrm{~g})$. Grinding hulls required a lot of energy and labor, and lowered the antioxidant activity as shown in Figure 5. The same trend was observed for soybean hulls as shown in Table 3. The protein contents were similar when compared ground hulls to unground hulls (C: $51.46 \%$ versus ground hulls G: $51.52 \%$ ). The recoveries using powders from acidic precipitates (G: 24.05\%), sediments (G: 68.92\%) and total recovery (G: $92.97 \%$ ) were slightly higher than from blended hulls (C: $22.99,65.62$, and $88.51 \%$, respectively). Directly using soybean hulls could be an alternative way to extract proteins in some situations.

\subsubsection{Homogenizing Methods}

Three homogenizing methods including polytron, blender and stirring were used for soybean hulls (Table 3). Polytron is a homogenizer that was tested in this study because the rotor/stator principle of polytron sounds like a good idea for grinding tough tissues by sonically disrupting the cells as well as mechanically. However, solids from polytron (Table 3A) were not easily separated after acidification possibly due to the hulls that were homogenized into very fine particles not separated by centrifugation. The stirred powdered sample recovered low solids (C: $0.89 \mathrm{~g}$ ) but had higher protein content (C: $51.46 \%$ ) than blended hulls stirred overnight (B: 43.06\%). However, the hull sample by blending had higher recovery (B: 25.73\%) than the one using stirring because the blended sample resulted in higher solids (B: $1.19 \mathrm{~g}$ ) than the sample with stirring (C: $0.89 \mathrm{~g})$. Thus, protein recovery is the function of dry weight and protein content. Results in this study indicate that overworked soybean hulls using polytron will affect protein separation, similar to double hot water extractions. Blending hulls could be an optimum way to process soybean hulls for extracting proteins.

\subsubsection{Separation Methods}

Two separation methods, centrifugation and sieve, were compared (Table 3, D and E). Soybean hulls using centrifugation had higher protein content (E: $47.02 \%$ ) than that from sieve separation (D: $34.56 \%$ ) in dried acid precipitates. However, protein recovery from acid precipitates (D: 28.46\%) using sieve method was higher than that using centrifugation (E: $16.05 \%$ ) due to high yield (D: $1.64 \mathrm{~g}$ ) from sieve separation. On the other hand, protein recovery from sediments (D: 64.12\%) using sieve method was lower than that using centrifugation method (E: $75.71 \%$ ). This indicated that centrifugation included some insoluble protein into the sediments by gravity. Total recovery using sieve separation (D: 92.58\%) was slightly higher than that of centrifuge separation (E: $91.76 \%$ ). Thus, sieve separation could be an effective way to extract protein from hulls for industrial application.

\subsubsection{Times for Purification}

Acid precipitation can be washed using water to gain higher protein content. In Table 3, G, H, and I were without washing, and washing once or twice, respectively (Table 3). The protein contents significantly increased from $51.52 \%(\mathrm{G})$ to $59.29 \%(\mathrm{H})$ by washing once but no improvement was seen when washing twice (I: $58.67 \%$ ). Without washing (G: $24.05 \%$ ) and washing once (H: $24.11 \%$ ) had similar recoveries that were higher than from washing twice (I: 12.66\%). The total recoveries were decreased with the increasing wash times. This suggests that washing precipitates can increase the protein content, but the total recoveries decreased, indicating that some soluble proteins were lost during washing.

\subsection{7 $\mathrm{NaOH}$ Versus $\mathrm{Ca}(\mathrm{OH})_{2}$}

Besides $\mathrm{NaOH}, \mathrm{Ca}(\mathrm{OH})_{2}$ could be used for increasing $\mathrm{pH}$ and digesting hulls. In Table 3, using $\mathrm{NaOH}$ had higher protein content (C: $51.46 \%)$, protein recovery (C: $22.99 \%)$ from acidic precipitates, and total recovery (C: $88.51 \%$ ) than using $\mathrm{Ca}(\mathrm{OH})_{2}$, which had protein content (F: 40.83\%), protein recovery $(\mathrm{F}: 16.4 \%)$ from precipitates, and total recovery (F: 75.91\%). These results were consistent with a previous observation (Paker, et al., 2017). In their study, the protein solubility was greater when $\mathrm{Ca}(\mathrm{OH})_{2}$ was used compared to $\mathrm{NaOH}$; also, using $\mathrm{Ca}(\mathrm{OH})_{2}$ as the processing base yielded the greatest lipid recovery $(p<0.05)$ at $77 \mathrm{~g}^{100 \mathrm{~g}^{-1}}$, whereas the

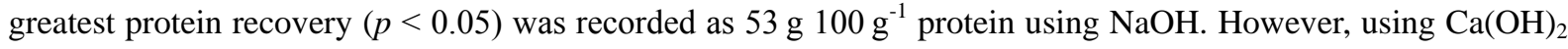
gave lighter color for products, and increased $\mathrm{Ca}$ content which is a valuable nutrient for health. 
Table 2. Comparisons of $\mathrm{pH}$, temperature, defatting, and hull versus powder for extracting value-added products from soybean hulls $(10 \mathrm{~g})$

\begin{tabular}{|c|c|c|c|c|c|c|c|c|c|c|}
\hline \multirow{2}{*}{$\begin{array}{l}\mathrm{T} \\
\#\end{array}$} & \multirow[t]{2}{*}{ materials } & \multirow[b]{2}{*}{$\mathrm{pH}$} & \multirow{2}{*}{$\begin{array}{l}\text { procedure } \\
\text { description }\end{array}$} & \multicolumn{2}{|c|}{ dried precipitates } & \multicolumn{4}{|c|}{ dried sediments } & \multirow{2}{*}{$\begin{array}{l}\text { total } \\
\text { recovery } \\
\%\end{array}$} \\
\hline & & & & $\begin{array}{l}\text { dry weight } \\
\text { (g) }\end{array}$ & $\begin{array}{l}\text { protein } \\
\%\end{array}$ & $\begin{array}{l}\text { recovery } \\
\%\end{array}$ & $\begin{array}{l}\text { dry weight } \\
\text { (g) }\end{array}$ & $\begin{array}{l}\text { protein } \\
\%\end{array}$ & $\begin{array}{l}\text { recovery } \\
\%\end{array}$ & \\
\hline 1 & powder & 7.5 & cold, single, stir & $0.38^{\mathrm{d}}$ & $38.54^{\mathrm{e}}$ & $22.09^{f}$ & - & - & - & - \\
\hline 2 & powder & 9 & hot, single, stir & $0.69^{\mathrm{a}}$ & $30.35^{f}$ & $24.64^{c}$ & - & - & - & - \\
\hline 3 & powder & 9 & cold, single, stir & $0.37^{\mathrm{d}}$ & $52.58^{\mathrm{a}}$ & $22.89^{\mathrm{e}}$ & - & - & - & - \\
\hline 4 & powder & 10 & cold, single, stir & $0.47^{\mathrm{c}}$ & $51.52^{b}$ & $24.05^{d}$ & 8.12 & 8.46 & 68.92 & 92.97 \\
\hline 5 & powder & 11 & cold, singly, stir & $0.39^{d}$ & $48.44^{\mathrm{c}}$ & $22.09^{f}$ & 7.99 & 6.19 & 58.16 & 80.26 \\
\hline 6 & defatted powder & 10 & cold, single, stir & $0.46^{\mathrm{c}}$ & $52.75^{\mathrm{a}}$ & $26.38^{b}$ & 8.29 & 6.02 & 54.25 & 80.63 \\
\hline 7 & defatted powder & 10 & hot, double, stir & $0^{\mathrm{e}}$ & $0^{g}$ & $0^{\mathrm{g}}$ & 7.69 & 8.73 & 72.96 & 72.96 \\
\hline 8 & hull & 9 & cold, single, blend & $0.53^{b}$ & $45.85^{d}$ & $28.59^{a}$ & - & - & - & - \\
\hline
\end{tabular}

Means followed by the same letter within the same column were not significantly different $(p<0.05)$.

Table 3. Comparisons of homogenization, separation and purification methods for extracting value-added products from soybean hulls $(20 \mathrm{~g})$ at $\mathrm{pH} 10$

\begin{tabular}{|c|c|c|c|c|c|c|c|c|c|}
\hline \multirow{2}{*}{$\frac{\mathrm{T}}{\#}$} & \multirow[t]{2}{*}{ materials } & \multirow{2}{*}{$\begin{array}{l}\text { procedure } \\
\text { description }\end{array}$} & \multicolumn{3}{|c|}{ dried precipitates } & \multicolumn{3}{|c|}{ dried sediments } & \multirow{2}{*}{$\begin{array}{l}\text { total } \\
\text { recovery } \\
\%\end{array}$} \\
\hline & & & $\begin{array}{l}\text { dry weight } \\
\text { (g) }\end{array}$ & $\begin{array}{l}\text { protein } \\
(\%)\end{array}$ & $\begin{array}{l}\text { recovery } \\
\%\end{array}$ & $\begin{array}{l}\text { dry weight } \\
\text { (g) }\end{array}$ & $\begin{array}{l}\text { protein } \\
\%\end{array}$ & $\begin{array}{l}\text { recovery } \\
\%\end{array}$ & \\
\hline A & hull & polytron, stir overnight & $1.75^{\mathrm{a} *}$ & $13.71^{\mathrm{h}}$ & $12.06^{\mathrm{h}}$ & $14.98^{\mathrm{f}}$ & $8.88^{\mathrm{b}}$ & $66.72^{c}$ & $78.78^{\mathrm{h}}$ \\
\hline B & hull & blend, stir overnight & $1.19^{\mathrm{c}}$ & $43.06^{\mathrm{e}}$ & $25.73^{\mathrm{b}}$ & $15.99^{\mathrm{e}}$ & $7.88^{\mathrm{g}}$ & $63.21^{\mathrm{g}}$ & $88.94^{\mathrm{d}}$ \\
\hline $\mathrm{C}$ & hull & blend, stir, purified once & $0.89^{\mathrm{d}}$ & $51.46^{\mathrm{c}}$ & $22.99^{d}$ & $15.94^{\mathrm{e}}$ & $8.19^{\mathrm{e}}$ & $65.52^{\mathrm{e}}$ & $88.51^{\mathrm{e}}$ \\
\hline $\mathrm{D}$ & hull & blend, stir, sieve & $1.64^{\mathrm{b}}$ & $34.56^{\mathrm{g}}$ & $28.46^{\mathrm{a}}$ & $14.16^{\mathrm{g}}$ & $9.02^{\mathrm{a}}$ & $64.12^{\mathrm{f}}$ & $92.58^{\mathrm{b}}$ \\
\hline $\mathrm{E}$ & hull & blend, stir, centrifuge & $0.68^{\mathrm{f}}$ & $47.02^{d}$ & $16.05^{\mathrm{f}}$ & $17.36^{\mathrm{a}}$ & $8.69^{c}$ & $75.71^{\mathrm{a}}$ & $91.76^{\mathrm{c}}$ \\
\hline $\mathrm{F}$ & hull & blend, stir, $\mathrm{Ca}(\mathrm{OH})_{2}$ & $0.80^{\mathrm{e}}$ & $40.83^{\mathrm{f}}$ & $16.40^{\mathrm{e}}$ & $16.12^{\mathrm{d}}$ & $7.35^{\mathrm{h}}$ & $59.51^{\mathrm{h}}$ & $75.91^{\mathrm{i}}$ \\
\hline G & powder & stir & $0.93^{\mathrm{d}}$ & $51.52^{\mathrm{c}}$ & $24.05^{c}$ & $16.23^{\mathrm{c}}$ & $8.46^{\mathrm{d}}$ & $68.92^{b}$ & $92.97^{\mathrm{a}}$ \\
\hline $\mathrm{H}$ & powder & stir, purified & $0.81^{\mathrm{e}}$ & $59.29^{\mathrm{a}}$ & $24.11^{\mathrm{c}}$ & $15.94^{\mathrm{e}}$ & $7.06^{\mathrm{i}}$ & $56.51^{\mathrm{i}}$ & $80.62^{f}$ \\
\hline I & powder & stir, purified twice & $0.43^{\mathrm{g}}$ & $58.67^{\mathrm{b}}$ & $12.66^{\mathrm{g}}$ & $16.59^{\mathrm{b}}$ & $7.96^{\mathrm{f}}$ & $66.28^{\mathrm{d}}$ & $78.94^{\mathrm{h}}$ \\
\hline
\end{tabular}

*Dried whole supernatant.

Means followed by the same letter within the same column are not significantly different $(p<0.05)$.

\subsection{Value-added Products}

\subsubsection{Extracted Protein}

The extracted protein (50-60\%) can be used protein-rich food products or used in other applications (Photo 1).

\subsubsection{Ingredients Rich in Proteins, Fibers, Minerals and Phytosterols}

The finely ground power from soybean hulls, dried sediments and whole freeze-dried supernatants may be good food ingredients for various purposes (Photo 1). The ground powder from hulls and the sediments from protein extractions containing 8-9\% proteins are excellent food ingredients that can be directly used in baking products, such as cookies and energy bars. In addition, neutralized whole supernatant from extraction after alkane treatment can be freeze-dried (Photo 1), and would be an excellent soluble ingredient with about 13\% protein that was higher than in the starting materials $(9-10 \%)$. The freeze-dried whole supernatant can be used in food products, such as dressings or toppings since it is water soluble. Furthermore, soybean hulls may be developed into valuable supplements with high protein, dietary fiber, minerals, and phytosterols due to their excellent antioxidant activity and nutritional value.

In this primary study, about $25-29 \%$ protein was able to be extracted from soybean hulls, regardless of $\mathrm{pH}$, homogenization and separation methods. This could be due to the protein in hulls tightly bound with fibers and lowere water solubility as shown in Table 1 . An earlier study found a lower recovery protein from plants which likely due to binding to fibers and varied among plant parts (Rothman, et al., 2008). Therefore, the proportion of fiber-bound protein should be considered when estimating protein, and further research is needed. 


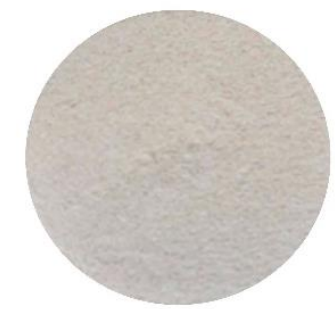

organic soybean hull powder (9.96\% protein)

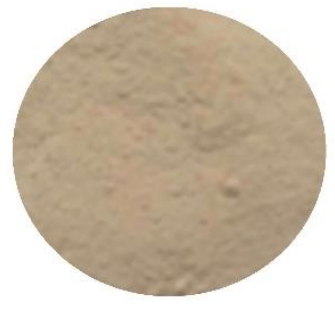

sediment (using $\mathrm{Ca}(\mathrm{OH})_{2}$, $\sim 7-8 \%$ protein)

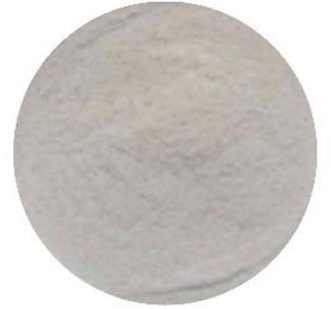

defatted organic soybean hull powder (10.13\% protein)

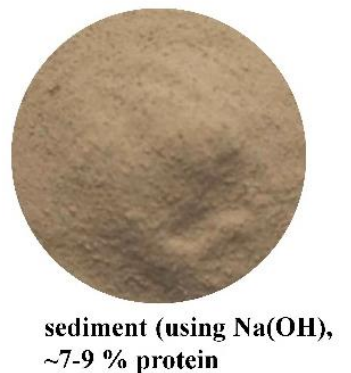

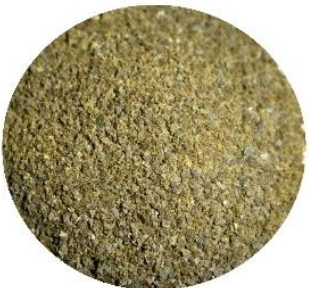

Proteins from soybean hulls ( $\sim 60 \%$ protein)

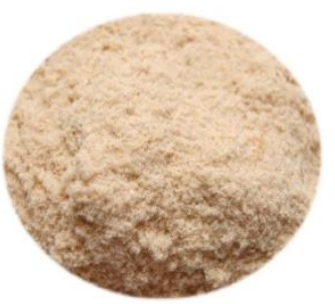

Freeze-dried whole neutralized supernatants ( 14\% protein)

Figure 7. Ground soybean hulls and potential value-added products

\section{Conclusion}

This research unveiled the nutritional value of soybean hulls and first reported antioxidant activity, pasting and water properties of soybean hulls. Also, various protein extraction methods were studied for valuable products from soybean hulls. The extraction at $\mathrm{pH} 9-10$ had higher protein recoveries compared to $\mathrm{pH} 7.5$ and 11 . Total recovery using sieve separation (92.58\%) is slightly higher than that of centrifugation $(91.76 \%)$. Using sieve separation could be an effective way to extract protein from soybean hulls for industrial application. The precipitated protein content from extracted supernatant (51.52\%) increased to $59.29 \%$ after purification by washing with water once. No further improvement was shown with two washings.

Several potential products were revealed in this research. The purified proteins can be used for food or industrial applications. The ground hull powders (10\% protein), dried supernatant (14\% protein), and sediments (7-8\% protein) along with antioxidant activity and valuable fibers will be tested to see if they can be good food ingredients in a future study. This research explored the great potential to covert soybean hulls from low value byproducts into value-added functional food or industrial products along with the benefit of reducing waste in the environment

\section{Acknowledgement}

Mention of trade names or commercial products in this article is solely for the purpose of providing scientific information and does not imply recommendation or endorsement by the U.S. Department of Agriculture. USDA is an equal opportunity provider and employer.

\section{References}

Ade-Omowaye, B. I. O., Taiwo, K. A., Eshtiaghi, N. M., Angersbach, A., \& Knorr, D. (2003). Comparative Evaluation of the Effects of Pulsed Electric Field and Freezing on Cell Membrane Permeabilisation and Mass Transfer during Dehydration of Red Bell Peppers. Innovative Food Science \& Emerging Technologies, 4, 177-188. https://dx.doi.org/10.1016/S1466-8564(03)00020-1

American Association of Cereal Chemists. (1995). Crude protein - Combustion method. In: American Association of Cereal Chemists Official Methods, 9th edition. St. Paul, MN: The Association, method 46-30.01

Anderson, S. J., Merrill, J. K., McDonnell, M. L., \& Klopfenstein, T. J. (1988). Digestibility and utilization of mechanically processed soybean hulls by lambs and steers. Journal of Animal Science, 66(11), 2965-2976. https:// dx.doi.org/10.2527/jas1988.66112965x 
Berk, Z. (1992). Isolated soybean proteins (ISP). Chapter 6. In: Technology of production of edible flours and protein products from soybeans. FAO Agricultural Service Bulletin. No.97. Food and Agriculture Organization of the United Nations. Rome, Italy. Retrieved from https://www.fao.org/3/t0532e/t0532e07.htm

Dyke, L., \& Rooney, L. W. (2007). Phenolic compounds in cereal grains and their health benefits. Cereal Foods World, 52, 105-111. https://doi.org/10.1094/CFW-52-3-0105QD1004316358

Extension. (2019). Retrieved from https://articles.extension.org/pages/39695/what-are-soybean-hulls.

Gnanasambandam, R., \& Proctor, A. (1997). Soy hull as an adsorbent source in processing soy oil. JAOCS, Journal of the American Oil Chemists' Society, 74, 685-692. https://dx.doi.org/10.1007/s11746-997-0201-2

Israelachvili, J. N. (2011). Intermolecular and Surface Forces. $3^{\text {rd }}$ Edition. Academic Press, an Imprint of Elsevier, Waltham, MA. pp. 152.

Kansas State University Agricultural Experiment Station and Cooperative Extension Service. (2019). Soybean Hulls: Composition and Feeding Value for Beef and Dairy Cattle. https://www.bookstore.ksre.ksu.edu/pubs/MF2438.pdf

Kasote, D. M., Katyare, S. S., Hegde, M. V., \& Bae, H. (2015). Significance of antioxidant potential of plants and its relevance to therapeutic applications. International Journal of biological Sciences, 11, 982-991. https://dx.doi.org/10.7150/ijbs.12096

Kaur, M., \& Singh, N. (2006). Relationships between selected properties of seeds, flours, and starches from different chickpea cultivars. International Journal of Food Properties, 9, 597-608. https:// dx.doi.org/10.1080/10942910600853774

Liu, K. (1999). Soybeans. Chemistry, Technology, and Utilization. Aspen publishers Inc., Gaithersburg, MD. pp. 387

Marshall, W. E., Wartelle, L. H., Boler, D. E., \& Toles, C. (2000). Metal ion adsorption by soybean hulls modified with critic acid: a comparative study. Environmental Technology, 21, 601-607. https://dx.doi.org/10.1080/09593332108618075

Mauri, A. N., \& Añón, M. C. (2006). Effect of solution pH on solubility and some structural properties of soybean protein isolate films. Journal of the Science of Food and Agriculture, 86, 1064-1072. https://dx.doi.org/10.1002/jsfa.2457

Paker, I., Jaczynski, J., \& Matak, K. E. (2017). Calcium hydroxide as a processing base in alkali-aided pH-shift protein recovery process. Journal of the Science of Food and Agriculture, 97, 811-817. http://dx.doi.org/10.1002/jsfa.7800.

Qiu, S., Yadav, M. P., \& Yin, L. (2017). Characterization and functionalities study of hemicellulose and cellulose components isolated from sorghum bran, bagasse and biomass. Food Chem., 230, 225-233. https://doi.org/10.1016/j.foodchem.2017.03.028.

Rothman, J. M., Chapman, C. A., \& Pell, A. N. (2008). Fiber-bound nitrogen in gorilla diets: implications for estimating dietary protein intake of primates. American Journal of Primatology, 70, 690-4. http://dx.doi.org/10.1002/ajp.20540

SAS Institute Inc. The SAS $^{\circledR}$ system for Windows ${ }^{\circledR}$, version 8e. Cary, NC. 1999.

Şensoy, I., Rosén, R. T., Ho, C. T., \& Karwe, M. V. (2006). Effect of Processing on Buckwheat Phenolics and Antioxidant Activity. Food Chemistry, 99, 388-393. http://dx.doi.org/10.1016/j.foodchem.2005.08.007

Sessa, D. J. (2004). Processing of soybean hulls to enhance the distribution and extraction of value-added proteins. Journal of the Science of Food and Agriculture, 84, 75-82. https://doi.org/10.1002/jsfa.1612

Stein, H. H., Berger, L. L., Drackley, J. K., Fahey, G. C., Jr., Hernot, D. C., \& Parsons, C. M. (2008). Nutritional Properties and Feeding Values of Soybeans and Their Coproducts. In L. A. Johnson, P. J. White, \& R. Galloway (Eds.), Soybeans: Chemistry, Production, Processing, and Utilization. (pp. 613-660). AOCS Press, Urbana IL. https://doi.org/10.1016/B978-1-893997-64-6.50021-4

Waterhouse, A. L. (2001). Determination of total phenolics. In: R. E. Wrolstad, Current Protocols in Food Analytical Chemistry, I1.1.1-I1.1.8. New York: John Wiley \& Sons.

Yu, L., \& Zhou, K. (2004). Antioxidant properties of bran extracts from Platte wheat grown at different locations. Food Chemistry, 90, 311-316. https://dx.doi.org/10.1016/j.foodchem.2004.04.007 


\section{Copyrights}

Copyright for this article is retained by the author(s), with first publication rights granted to the journal.

This is an open-access article distributed under the terms and conditions of the Creative Commons Attribution license (http://creativecommons.org/licenses/by/4.0/). 